\title{
Reporting oncoimaging in the appropriate oncology setting
}

\author{
S De Luca*, C Carrera, E Casalini Vañek, L Tolkachier, L Alarcon, E Eyheremendy \\ From International Cancer Imaging Society Meeting and 15th Annual Teaching Course (ICIS 2015) \\ London, UK. 5-7 October 2015
}

\section{Learning objectives}

Demonstrate the importance of multidisciplinary interrelationship between the oncologist and the radiologist for correct imaging interpretation.

Illustrate in a pictorial essay scenario, cases in which, considering clinical condition, laboratory values, complementary examinations and evolution of lesions on imaging exams are essential for an adequate presumptive diagnosis.

\section{Content organisation}

The cases we will present include:

Young male patient with malignant germ cell tumour, treated with bleomycin. With pulmonary small nodules in a control MDCT suspected of metastasis in the setting of negative humoral markers and surgical biopsy confirmed drug hypersensitivity.

Male patient with mixed germ cell tumour in control MDCT which derived to PET CT demonstrated new hypermetabolic lymphadenopathy of mediastinum without elevated humoral markers and biopsy by mediastinoscopy confirmed sarcoidosis.

Patient with colorectal adenocarcinoma with lung, liver and adrenal metastasis in the context of onset of dyspnea. According to RECIST criteria represented a pulmonary stable disease but one of the nodules produced greater extrinsic compression of the nearest main bronchus so we considered real progressive disease clarifying that we did not take into account the classical criteria.

A woman with locally advanced colorectal adenocarcinoma with rapidly progressive multinodular pleuropulmonar, brain commitment and fever. We suspected infectious origin and resulted nocardia concomitant infection.

\section{Conclusion}

We emphasise the importance of adequate clinical information and multidisciplinary interrelationship for the correct imaging interpretation in oncological patients.

Published: 2 October 2015

doi:10.1186/1470-7330-15-S1-P32

Cite this article as: De Luca et al:: Reporting oncoimaging in the appropriate oncology setting. Cancer Imaging 2015 15(Suppl 1):P32.

Submit your next manuscript to BioMed Central and take full advantage of:

- Convenient online submission

- Thorough peer review

- No space constraints or color figure charges

- Immediate publication on acceptance

- Inclusion in PubMed, CAS, Scopus and Google Scholar

- Research which is freely available for redistribution

\footnotetext{
* Correspondence: sdeluca@hospitalaleman.com
} Hospital Aleman, Buenos Aires, Argentina 